\title{
PERANGKAT PEMBELAJARAN MATEMATIKA BERBASIS SMART \\ (Specific, Measurable, Achievable, Realistic, and Time-bound)
}

Oleh:

Muchamad Subali Noto

Pendidikan Matematika FKIP Universitas Swadaya Gunung Jati balimath61@gmail.com

\begin{abstract}
ABSTRAK
Pengembangkan perangkat pembelajaran menggunakan modifikasi model 4-D (menjadi 3D) Thiagarajan yaitu sebagai berikut: (1) pendefinisian, (2) perancangan, dan (3) pengembangan. Perangkat pembelajaran yang dikembangkan adalah (1) Silabus, (2) Rencana Pelaksanaan Pembelajaran (RPP), (3) Modul. Data diperoleh melalui lembar validasi, tes prestasi belajar. Data diolah dengan deskriptif, analisis uji banding sample $t$ test. Proses pengembangan perangkat menghasilkan: 1 . Perangkat pembelajaran adalah valid setelah melalui revisi berdasarkan penilaian para ahli dan teman sejawat. Hasil penilaian akhirnya diperoleh rata-rata nilai validitas Silabus 3.36, RPP 3.24, dan validitas Modul 3.23 (skor tertinggi 4) termasuk kriteria valid, 2. Implementasi perangkat pembelajaran menyatakan prestasi belajar siswa kelas uji coba perangkat dengan rata-rata 70.33 lebih baik dari pada prestasi belajar siswa pada kelas kontrol dengan rata-rata 60,60. Berdasarkan hasil perangkat valid dan pembelajaran efektif menunjukkan pengembangan perangkat tercapai.
\end{abstract}

Kata Kunci : perangkat pembelajaran, SMART

\begin{abstract}
Developing a teaching intruments using a modified model of 4-D (to 3D) Thiagarajan is as follows: (1) Definition, (2) Design, and (3) Development. Teaching instruments was developed (1) Syllabus, (2) Lesson Plan, (3) Module. Data obtained through the sheet validation, test learning achievement. The data were processed with descriptive and comparative analysis sample t test. Development process instruments resulted in: 1 . Teaching instruments is valid after revision based on the assessment of experts and peers. Assessment results finally obtained an average value Syllabus validity 3,36; Lesson Plan 3,24; and validity module is 3,23 (highest score 4) include a valid criterion, 2 . Implementation of the stated learning class student achievement test instruments with an average of 70,33 better than the learning achievement of students in the control class with an average of 60.60 . Based on the results of a valid and effective teaching instruments shows the development achieved.
\end{abstract}

Keywords : Teaching Instruments, SMART 


\section{PENDAHULUAN}

\subsection{Latar Belakang}

Pembelajaran matematika mempunyai posisi yang strategis untuk menumbuhkembangkan kemampuan nalar siswa dan dapat dipandang sebagai latihan untuk menata nalar atau khususnya untuk geometri dapat memberikan wawasan keruangan siswa. Namun keadaan di lapangan menunjukkan bahwa penguasan matematika khususnya materi geometri oleh siswa masih lemah. Salah satu kelemahan penguasaan materi geometri oleh siswa adalah karena sukar mengenali dan memahami bangun-bangun geometri, juga metode yang digunakan guru kurang melibatkan aktivitas siswa.

Gambaran kemampuan penguasaan materi geometri seperti materi segiempat yang masih rendah berdampak pada hasil belajar yang belum memuaskan. Melalui pembelajaran dengan perangkat pembelajaran seperti RPP, Buku Guru, LKS dan alat peraga yang digunakan guru secara klasikal, ternyata belum mampu meningkatkan hasil belajar siswa. Pembelajaran umumnya dilaksanakan juga belum mampu menumbuhkan keaktifan dan keterampilan proses yang memuaskan. Kenyataan tersebut memerlukan perhatian dan kreatifitas guru untuk mengembangkan perangkat pembelajaran dan model pembelajaran yang menjadikan siswa lebih aktif, kreatif dan efektif serta mampu meningkatkan pemahaman konsep siswa.

Sehubungan dengan hal tersebut perlu adanya suatu perangkat pembelajaran meningkatkan kemampuan siswa dan hasil belajar siswa. Salah satunya yaitu melakukan pengembangan perangkat pembelajaran dengan berbasis specific, measurable, achievable, realistic, dan time bound (SMART), prinsipnya adalah mengembangkan perangkat yang pembelajarannya dirancang memenuhi indikatorindikator SMART.

Pengembangan perangkat pembelajaran adalah penyusunan perangkat pembelajaran yang meliputi Silabus, RPP, Modul yang memenuhi kriteria SMART. Dengan memperhatikan kekhususan materi yang sesuai dengan kurikulum dan sesuai dengan tingkat kemampuan siswa (Spesifik), keterukuran indikator dari pemilihan materi yang spesifik (Measurable), bahwa indikator yang terukur tadi jelas dapat dicapai dengan ditunjukkan oleh ketuntasan hasil kelak (Achievable: ketercapaian atau prestasi), bahwa materi terukur agar mencapai keberhasilan atau ketercapaian harus diantarkan oleh suatu langkah yang realistik yakni kejelasan skenario dari awal proses hingga akhir real untuk dilaksanakan dan pada akhirnya alat ukurnya juga real jelas (Realistik), tentu saja untuk mencapai semua itu jelas dan hasil dapat ditunjukkan dengan menggunakan batas tertentu yang lebih efisein dan efektif dari pada sebelumnya (Time bond). 
Dalam makalah ini penulis maknai sebagai perlunya perangkat pembelajaran berbasis SMART.

\subsection{Rumusan Masalah}

Berdasarkan uraian pada latar belakang, dapat dirumuskan permasalahan sebagai berikut.

1. Apa sajakah Indikator-indikator perangkat pembelajaran matematika berbasis SMART yang harus dipenuhi?

2. Apakah terdapat perbedaan rata-rata nilai prestasi siswa untuk kelas yang menggunakan perangkat pembelajaran matematika berbasis SMART dengan yang tidak?

\subsection{Batasan Istilah}

Berikut ini akan disajikan beberapa istilah penting yang digunakan.

1. Perangkat pembelajaran berupa silabus, Rencana Pelaksanaan Pembelajaran, dan Modul.

2. Pengembangan perangkat pembelajaran menggunakan model 4D Thiagarajan, Semmel dan Semmel (1974: 5) yang telah dimodifikasi menjadi $3 D$ Model yakni Define (pendefinisian), Design (desain), Develop (pengembangan).

\section{KAJIAN PUSTAKA}

\subsection{Perangkat Pembelajaran}

Perangkat pembelajaran adalah sekumpulan sumber belajar yang digunakan guru dan peserta didik dalam kegiatan pembelajaran. Pengembangan perangkat pembelajaran berbasis SMART dibatasi hanya pada pengembangan perangkat yang berupa:

\subsubsection{Silabus dan Rencana Pelaksanaan Pembelajaran (RPP)}

RPP disusun untuk setiap KD yang dapat dilaksanakan dalam satu kali pertemuan atau lebih. Guru merancang penggalan RPP untuk setiap pertemuan yang disesuaikan dengan penjadwalan di satuan pendidikan.

Komponen RPP adalah:

1. Identitas mata pelajaran, meliputi: (a) satuan pendidikan; (b) kelas; (c) semester; (d) program studi ; (e) mata pelajaran atau tema pelajaran dan (f) jumlah pertemuan.

2. Standar Kompetensi, merupakan kualifikasi kemampuan minimal peserta didik yang menggambarkan penguasaan pengetahuan, sikap, dan keterampilan yang 
diharapkan dicapai pada setiap kelas dan/atau semester pada suatu mata pelajaran.

3. Kompetensi Dasar

Kompetensi Dasar adalah sejumlah kemampuan yang harus dikuasai peserta didik dalam mata pelajaran tertentu sebagai rujukan penyusunan indikator kompetensi dalam suatu pelajaran.

4. Indikator Pencapaian Kompetensi,

Merupakan perilaku yang dapat diukur dan/atau diobservasi untuk menunjukkan ketercapaian kompetensi dasar tertentu yang menjadi acuan penilaian mata pelajaran. Indikator pencapaian kompetensi dirumuskan dengan menggunakan kata kerja operasional yang dapat diamati dan diukur, yang mencakup pengetahuan, sikap, dan keterampilan.

5. Tujuan Pembelajaran,

Menggambarkan proses dan hasil belajar yang diharapkan dicapai oleh peserta didik sesuai dengan kompetensi dasar.

6. Materi Ajar,

Memuat fakta, konsep, prinsip, dan prosedur yang relevan, dan ditulis dalam bentuk butir-butir sesuai dengan rumusan indikator pencapaian kompetensi.

7. Alokasi Waktu,

Ditentukan sesuai dengan keperluan untuk pencapaian KD dan beban belajar.

8. Metode Pembelajaran,

Digunakan oleh guru untuk mewujudkan suasana belajar dan proses pembelajaran agar peserta didik mencapai kompetensi dasar atau seperangkat indikator yang telah ditetapkan. Pemilihan metode pembelajaran disesuaikan dengan situasi dan kondisi peserta didik, serta karakteristik dari setiap indikator dan kompetensi yang hendak dicapai pada setiap mata pelajaran.

9. Kegiatan Pembelajaran

a. Pendahuluan

Pendahuluan merupakan kegiatan awal dalam suatu pertemuan pembelajaran yang ditujukan untuk membangkitkan motivasi dan memfokuskan perhatian peserta didik untuk berpartisipasi aktif dalam proses pembelajaran.

b. Inti

Kegiatan inti merupakan proses pembelajaran untuk mencapai KD. Kegiatan pembelajaran dilakukan secara interaktif, inspiratif, menyenangkan, menantang, memotivasi peserta didik untuk berpartisipasi aktif, serta memberikan ruang yang cukup bagi prakarsa, kreativitas, dan kemandirian 
sesuai dengan bakat, minat, dan perkembangan fisik serta psikologis peserta didik. Kegiatan ini dilakukan secara sistematis dan sistemik melalui proses eksplorasi, elaborasi, dan konfirmasi.

c. Penutup

Penutup merupakan kegiatan yang dilakukan untuk mengakhiri aktivitas pembelajaran yang dapat dilakukan dalam bentuk rangkuman atau simpulan, penilaian dan refleksi, umpan balik, dan tindaklanjut.

d. Penilaian hasil belajar

Prosedur dan instrumen penilaian proses dan hasil belajar disesuaikan dengan indikator pencapaian kompetensi dan mengacu kepada Standar Penilaian.

10. Sumber belajar

Penentuan sumber belajar didasarkan pada standar kompetensi dan kompetensi dasar, serta materi ajar, kegiatan pembelajaran, dan indikator pencapaian kompetensi.

\subsubsection{Modul}

Modul merupakan salah satu bentuk bahan ajar yang dikemas secara utuh dan sistematis, didalamnya memuat seperangkat pengalaman belajar yang terencana dan didesain untuk membantu peserta didik menguasai tujuan belajar yang spesifik (Depdiknas. 2008). Modul minimal memuat tujuan pembelajaran, materi/substansi belajar, dan evaluasi. Modul berfungsi sebagai sarana belajar yang bersifat mandiri, sehingga peserta didik dapat belajar sesuai dengan kecepatan masing-masing. Untuk menghasilkan modul yang mampu meningkatkan motivasi belajar, pengembangan modul harus memperhatikan karakteristik yang diperlukan sebagai modul.

\section{Self Instruction}

Merupakan karakteristik penting dalam modul, dengan karakter tersebut memungkinkan seseorang belajar secara mandiri dan tidak tergantung pada pihak lain.

Untuk memenuhi karakter self instruction, maka modul harus:

a. Memuat tujuan pembelajaran yang jelas, dan dapat menggambarkan pencapaian Standar Kompetensi dan Kompetensi Dasar.

b. Memuat materi pembelajaran yang dikemas dalam unit-unit kegiatan yang kecil/spesifik, sehingga memudahkan dipelajari secara tuntas;

c. Tersedia contoh dan ilustrasi yang mendukung kejelasan pemaparan materi pembelajaran;

d. Terdapat soal-soal latihan, tugas dan sejenisnya yang memungkinkan untuk mengukur penguasaan peserta didik; 
e. Kontekstual, yaitu materi yang disajikan terkait dengan suasana, tugas atau konteks kegiatan dan lingkungan peserta didik;

f. Menggunakan bahasa yang sederhana dan komunikatif,

g. Terdapat rangkuman materi pembelajaran;

h. Terdapat instrumen penilaian, yang memungkinkan peserta didik melakukan penilaian mandiri (self assessment);

i. Terdapat umpan balik atas penilaian peserta didik, sehingga peserta didik mengetahui tingkat penguasaan materi;

j. Terdapat informasi tentang rujukan/ pengayaan/referensi yang mendukung materi pembelajaran dimaksud.

\section{Self Contained}

Modul dikatakan self contained bila seluruh materi pembelajaran yang dibutuhkan termuat dalam modul tersebut. Tujuan dari konsep ini adalah memberikan kesempatan peserta didik mempelajari materi pembelajaran secara tuntas, karena materi belajar dikemas kedalam satu kesatuan yang utuh. Jika harus dilakukan pembagian atau pemisahan materi dari satu standar kompetensi/kompetensi dasar, harus dilakukan dengan hati-hati dan memperhatikan keluasan standar kompetensi/kompetensi dasar yang harus dikuasai oleh peserta didik.

\section{Berdiri Sendiri (Stand Alone)}

Stand alone atau berdiri sendiri merupakan karakteristik modul yang tidak tergantung pada bahan ajar/media lain, atau tidak harus digunakan bersama-sama dengan bahan ajar/media lain. Dengan menggunakan modul, peserta didik tidak perlu bahan ajar yang lain untuk mempelajari dan atau mengerjakan tugas pada modul tersebut. Jika peserta didik masih menggunakan dan bergantung pada bahan ajar lain selain modul yang digunakan, maka bahan ajar tersebut tidak dikategorikan sebagai modul yang berdiri sendiri.

\section{Adaptif}

Modul hendaknya memiliki daya adaptasi yang tinggi terhadap perkembangan ilmu dan teknologi. Dikatakan adaptif jika modul tersebut dapat menyesuaikan perkembangan ilmu pengetahuan dan teknologi, serta fleksibel/luwes digunakan di berbagai perangkat keras (hardware).

\section{Bersahabat/Akrab (User Friendly)}

Modul hendaknya juga memenuhi kaidah user friendly atau bersahabat/akrab dengan pemakainya. Setiap instruksi dan paparan informasi yang tampil bersifat membantu dan bersahabat dengan pemakainya, termasuk kemudahan pemakai dalam merespon dan mengakses sesuai dengan keinginan. Penggunaan bahasa yang sederhana, mudah dimengerti, serta menggunakan istilah yang umum digunakan, merupakan salah satu bentuk user friendly. 


\subsection{Model Pengembangan Perangkat Pembelajaran Menurut Thiagarajan, Semmer dan Semmer}

Menurut Thiagarajan, Semmel dan Semmel (1974: 5) dalam pengembangan pembelajaran digunakan model yang disebut Four-D Model (4D) yakni Define (pendefinisian), Design (desain), Develop (pengembangan), Disseminate (pendesiminasian). Deskripsikan secara singkat dapat ditunjukkan dalam Gambar 1 berikut.

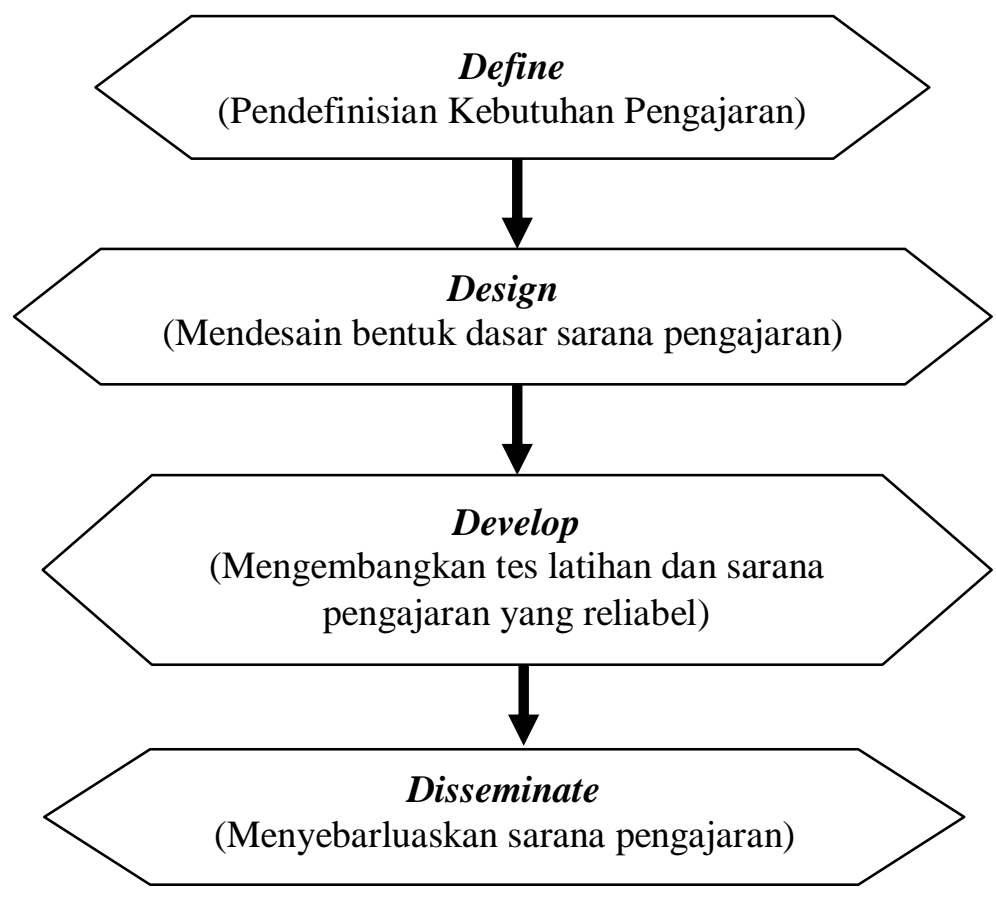

Keterangan :

: Urutan proses

Gambar 1 Four-D model (Thiagarajan, Semmel \& Semmel 1974: 5)

Keempat model tahap tersebut adalah :

\section{(1) Pendefinisian (Define)}

Tujuan tahap ini adalah menetapkan dan mendefinisikan syarat-syarat pembelajaran. Pada tahap awal ini dilakukan analisis untuk menentukan tujuan pembelajaran dan batasan materi yang akan dikembangkan. Tahap pendefinisian terdiri dari lima langkah yaitu :

a. Analisis awal-akhir. Langkah ini untuk menentukan masalah mendasar yang dihadapi pendidik. 
b. Analisis peserta didik. Langkah ini untuk menelaah peserta didik, dilakukan identifikasi terhadap karakteristik peserta didik yang sesuai dengan rancangan dan pengembangan pembelajaran.

c. Analisis tugas. Langkah ini merupkan pengidentifikasi keterampilanketerampilan utama yang diperlukan untuk menganalisisnya ke dalam suatu kerangka sub keterampilan.

d. Analisis konsep. Langkah ini digunakan untuk mengidentifikasi konsep-konsep utama yang akan diajarkan, menyusunnya secara hierarkis, dan memilah konsep-konsep individual.

e. Perumusan tujuan pembelajaran. Langkah ini digunakan untuk mengkonversikan hasil yang telah diperoleh pada langkah analisis tugas dan analisis konsep menjadi tujuan-tujuan khusus.

\section{(2) Perancangan (Design)}

Tujuan tahap ini adalah untuk merancang prototipe perangkat pembelajaran. Tahap ini dimulai setelah tujuan pembelajaran ditetapkan. Di dalam tahap ini terdapat empat langkah yang meliputi :

a. Pemilihan media. Langkah ini dilakukan untuk menentukan media yang tepat untuk penyajian materi pelajaran.

b. Pemilihan format. Langkah ini berkaitan erat dengan pemilihan media. Pemilihan format yang paling tepat bergantung pada banyak faktor yang dipertimbangkan dalam pembelajaran.

c. Desain awal. Langkah ini disajikan inti dari proses pembelajaran meliputi media yang dianggap paling tepat beserta kegiatan-kegiatan yang akan dilakukan dalam pembelajaran.

\section{(3) Pengembangan (Develop)}

Tujuan tahap ini adalah untuk menghasilkan prototipe perangkat pembelajaran. Sebelum diterapkan, perangkat yang telah dibuat harus melalui dua langkah, yaitu :

a. Penilaian tenaga ahli. Langkah ini dilakukan untuk memperoleh saran perbaikan. Beberapa ahli diminta untuk mengevaluasi perangkat pembelajaran. Berdasarkan saran mereka, perangkat pembelajaran diperbaiki sehingga lebih tepat, efektif, bermanfaatan dan berkualitas tinggi.

b. Uji coba perangkat pembelajaran untuk pengembangan. Langkah ini dilakukan uji coba terbatas siklus menguji, merevisi, dan menguji kembali dilakukan terus menerus sampai diperoleh perangkat pembelajaran yang konsisten dan efektif.

\section{(4) Penyebaran (Disseminate)}

Pengembangan perangkat pembelajaran mencapai tahap akhir jika telah memperoleh nilai positif dari tenaga ahli dan melalui tes pengembangan perangkat pembelajaran tersebt kemudian dikemas, disebarkan dan diterapkan untuk skala yang lebih luas. 


\subsection{SMART (Specific, Measurable, Achievable, Realistic, and Time-bound)}

Mengacu pada apa yang dikembangkan oleh Boise State University (2007), SMART berkenaan dengan akronim yang dikembangkan di sekitar karakteristik kunci berkenaan dengan tujuan penting sedemikian hingga dapat sangat membantu dalam menulis tujuan yang dapat dijadikan modal dalam mengevaluasi kualitas programprogram yang diajukan dan dilaksanakan.

\subsubsection{Indikator SMART}

Menurut Iverson (2003: 12), SMART dapat dipandang sebagai visi program yang berarti specific (spesifik), measurable (dapat diukur), achievable (dapat dipenuhi), realistic (realistik), time-bound (batasan waktu).

\section{Specific}

Specific berarti bahwa tujuannya adalah konkret, rinci, terfokus dan terdefinisi dengan baik. Program menyatakan hasil yang spesifik, atau tujuan yang tepat. Hasil dinyatakan dalam bilangan, persentase, frekuensi, pengamatan, hasil ilmiah dan lain lain. Untuk membantu tujuan agar spesifik dapat gunakan pertanyaan:

a. Apa yang akan dilakukan? ditulis menggunakan kata kerja aktif seperti mengarahkan, mengembangkan, membangun, merencanakan, melaksanakan, dll. Hal ini akan membantu untuk menjadi tindakan berorientasi dan berfokus pada apa yang paling penting.

b. Mengapa hal ini penting untuk dilakukan?

c. Siapa yang akan melakukan apa? Siapa lagi yang perlu dilibatkan?

d. Kapan ingin ini diselesaikan?

e. Bagaiman mengerjakan ini?

\section{Pertanyaan Diagnostik}

a. Apa sebenarnya yang akan kita lakukan, dengan atau untuk siapa?

b. Strategi-strategi apa yang akan digunakan?

c. Apakah tujuan dipahami dengan baik?

d. Apakah tujuan digambarkan dengan kata kerja aktif?

e. Apakah jelas siapa yang terlibat?

f. Apakah itu jelas di mana hal ini akan terjadi?

g. Apakah jelas apa yang dibutuhkan?

h. Apakah hasilnya jelas?

i. Apakah langkah ini tepat untuk hasil yang diinginkan?

\section{Measurable}

Measurable berarti dapat mengukur apakah telah mencapai tujuan atau tidak (bilangan, kuantitas, dan perbandingan). Tujuan itu dapat diukur terkandung maksud bahwa sumber pengukuran telah diidentifikasi dan dapat untuk menjalankan aksiaksi kemajuan terhadap tujuan. Pengukuran mempunyai hasil yang dapat dinilai, baik dalam skala 1-10 ataupun dalam bentuk keberhasilan dan kegagalan. 
Pengukuran merupakan jalan panjang yang membantu mengetahui kapan telah memenuhi tujuan.

Pertanyaan Diagnostik

a. Bagaimana mengetahui perubahan telah terjadi?

b. Pengukuran ini dapat diperoleh?

\section{Achievable}

Achievable menyangkut pertanyaan apakah tujuan yang dihimpun dapat dipenuhi dan dapat dicapai? tujuan harus dapat dicapai. Jika tujuan terlalu jauh di masa depan, harus hati-hati menjaga motivasi utnuk mencapainya. Tujuan memerlukan dorongan, tetapi jangan terlalu jauh karena akan dapat menyebabkan frustasi dan motivasi turun.

Pertanyaan Diagnostik

a. Bisakah melakukannya dalam jangka waktu tertentu?

b. Apakah memahami keterbatasan dan muatannya?

c. Bisakah melakukan hal ini dengan sumber daya yang kita miliki?

d. Sudahkah semua dikerjakan dengan baik?

e. Apakah ini mungkin?

\section{Realistic}

Realistic berarti bahwa memiliki sumber daya untuk menyelesaikannya. Pencapaian objektif memerlukan sumber daya seperti: kepegawaian, keahlian, uang, peralatan, dll. Sebagian besar tujuan dicapai tetapi mungkin memerlukan perubahan dalam prioritas untuk membuat mereka terjadi.

\section{Pertanyaan Diagnostik}

a. Apakah memiliki sumber daya yang tersedia untuk mencapai tujuan ini?

b. Apakah perlu untuk meninjau kembali prioritas untuk membuat hal ini terjadi?

c. Apakah mungkin untuk mencapai tujuan ini?

\section{Time-Bound}

Time-Bound berarti menetapkan batas waktu untuk pencapaian tujuan. Batas waktu perlu baik dapat dicapai dan realistis. Jika tidak menetapkan waktu akan mengurangi motivasi dan urgensi yang diperlukan untuk melaksanakan tugas. Mengkreasi waktu merupakan kebutuhan yang urgen dan tindakan yang tepat

\section{Pertanyaan Diagnostik}

a. Kapan tujuan ini dapat dicapai?

b. Apakah ada batas waktu yang dinyatakan?

\subsection{Perangkat Pembelajaran Yang Valid}

Perangkat pembelajaran dikatakan valid, jika memenuhi validitas isi, dan validitas konstruk yang ditentukan oleh para ahli. Perangkat pembelajaran yang dikembangkan dikatakan valid, jika setelah melalui proses (1) validasi ahli, (2) 
revisi berdasarkan hasil validasi ahli dan saran para ahli, (3) uji coba, (4) revisi berdasarkan hasil ujicoba perangkat pembelajaran (gafur, 1989; Trianto, 2007).

\section{METODE PENELITIAN}

\section{Prosedur Penelitian}

Model pengembangan perangkat pembelajaran yang digunakan merupakan modifikasi dari model 4-D yang dikemukakan Thiagarajan, Semmel dan Semmel (dalam Trianto 2007: 65) yang terdiri dari empat tahap. Keempat tahap tersebut adalah pendefinisian (define), perancangan (design), pengembangan (develop) dan tahap penyebaran (disseminate). Tahap pengembangan perangkat pembelajaran dimodifikasi menjadi 3D, hanya sampai pada tahap uji coba terbatas (develop).

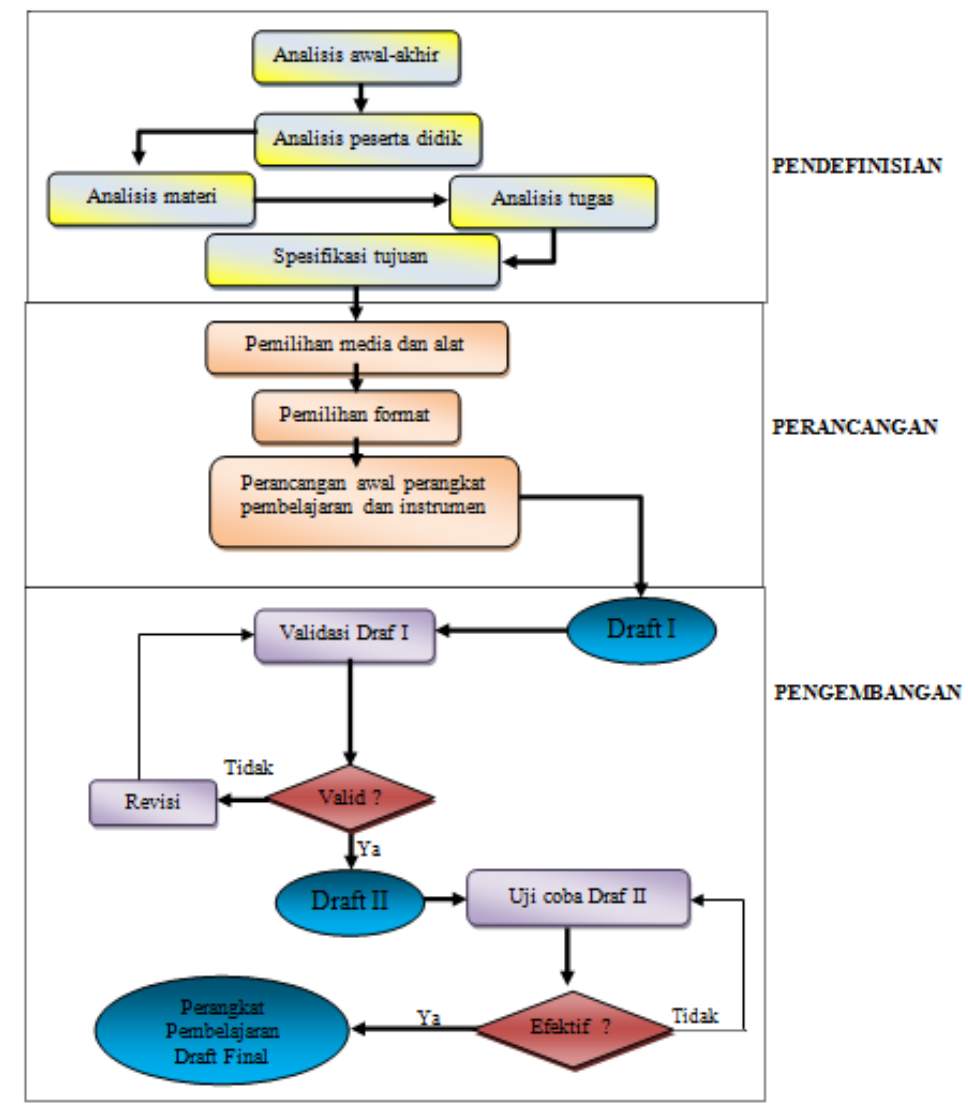

Keterangan:

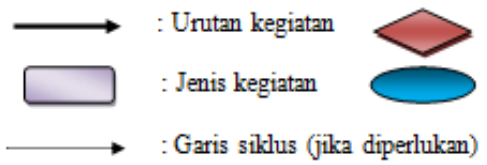

Hasil

: Keputusan

Gambar 2. Modifikasi model pengembangan perangkat 
Tahap pengembangan perangkat pembelajaran tersebut dapat diuraikan sebagai berikut.

1) Tahap Pendefinisian

Tahap ini bertujuan untuk menentukan dan mendefinisikan syarat-syarat yang dibutuhkan dalam pembelajaran dengan menganalisis tujuan dan batasan materi. Kegiatan yang dilakukan pada tahap ini adalah analisis awal-akhir (analisis kurikulum), analisis peserta didik, analisis materi, analisis tugas, dan spesifikasi tujuan pembelajaran.

2) Tahap Perancangan

Tahap ini bertujuan untuk merancang perangkat pembelajaran, sehingga diperoleh contoh perangkat pembelajaran. Kegiatan pada tahap ini adalah kriteria penyusunan tes, pemilihan media, pemilihan format dan perancangan awal yang dimulai setelah ditetapkan tujuan pembelajaran khusus.

3) Tahap Pengembangan

Tujuan dari tahap ini adalah untuk menghasilkan draft perangkat pembelajaran yang telah direvisi berdasarkan masukan para ahli dan data yang diperoleh dari hasil uji coba.

\section{Pembahasan}

\section{Pengembangan Perangkat Berbasis SMART}

Dengan mengacu konsep SMART, indikator-indikator SMART yang akan digunakan sebagai basis pengembangan perangkat dan kegiatan pembelajaran sebagai berikut:

\section{Specific}

Beberapa indikator spesific dalam pengembangan perangkat sebagai berikut.

a. Perangkat dan kegiatan pembelajaran yang dikembangkan sesuai dengan strategi yang digunakan.

b. Perangkat dan kegiatan pembelajaran yang dikembangkan memuat tujuan yang hendak dicapai.

c. Tujuan yang hendak dicapai digambarkan dengan kata kerja operasional.

d. Perangkat dan kegiatan pembelajaran yang dikembangkan memuat bagian petunjuk (hint) yang digunakan untuk membantu mengatasi kesulitan siswa.

\section{Measurable}

Beberapa indikator measurable dalam pengembangan perangkat sebagai berikut.

a. Perangkat dan kegiatan pembelajaran yang dikembangkan memuat instrumen yang digunakan untuk mengukur tingkat pencapaian tujuan/kompetensi. 
b. Instrumen yang dikembangkan sesuai dengan tujuan/kompetensi yang hendak dicapai.

c. Intrumen yang dikembangkan memuat penskoran yang jelas sehingga dapat mendeteksi batas kemampuan siswa.

\section{Achievable}

Beberapa indikator achievable dalam pengembangan perangkat sebagai berikut.

a. Perangkat dan kegiatan pembelajaran yang dikembangkan memuat sumber. alat, dan bahan yang digunakan untuk mencapai tujuan/kompetensi

b. Perangkat dan kegiatan pembelajaran yang dikembangkan mempunyai batasan dan muatan materi yang jelas.

c. Perangkat dan kegiatan pembelajaran yang dikembangkan memiliki sistematika dan alur proses yang jelas sehingga mudah untuk digunakan atau dilaksanakan.

\section{Realistic}

Beberapa indikator realistic dalam pengembangan perangkat sebagai berikut.

a. Perangkat dan kegiatan pembelajaran yang dikembangkan memuat upaya mencapai tujuan (instrumen) yang sesuai dengan kemampuan siswa.

b. Perangkat dan kegiatan pembelajaran yang dikembangkan memuat bagian yang digunakan untuk mengukur kemampuan awal (prasyarat) yang dimiliki siswa.

c. Perangkat dan kegiatan pembelajaran yang dikembangkan memberikan informasi tentang bagian fundamental dari materi yang dibahas.

\section{Time Bound}

Beberapa indikator time bound dalam pengembangan perangkat sebagai berikut.

a. Perangkat dan kegiatan pembelajaran yang dikembangkan memuat batasan waktu untuk mencapai tujuan/kompetensi tertentu.

b. Perangkat dan kegiatan pembelajaran yang dikembangkan memuat batasan waktu keseluruhan untuk mencapai semua tujuan/kompetensi.

\section{Validasi Perangkat Pembelajaran}

Para validator memberikan penilaian pada setiap aspek perangkat pembelajaran yang meliputi silabus, RPP, Modul. Hasil validasi disajikan dalam tabel 1 berikut.

Tabel 1. Hasil Validasi Validator Perangkat

\begin{tabular}{|c|l|c|c|}
\hline No & Jenis perangkat pembelajaran & Nilai rata-rata validasi & Kriteria validitas \\
\hline 1 & Silabus & 3,36 & valid \\
\hline 2 & $\begin{array}{l}\text { Rencana Pelaksanaan Pembelajaran } \\
\text { (RPP) }\end{array}$ & 3,24 & valid \\
\hline 3 & Modul & 3,23 & valid \\
\hline Jumlah Total Skor Validitas & 9,83 & valid \\
\hline Banyaknya Aspek Penilaian Perangkat & 3 & \\
\hline $\begin{array}{l}\text { Rata-rata Skor Validitas Perangkat } \\
\text { Pembelajaran }\end{array}$ & $9,83 / 3=3,28$ & \\
\hline
\end{tabular}


Dalam hal ini rata-rata validator menilai baik karena dalam pengerjaan perangkat ini perangkat yang dikembangkan valid kerena sudah melalui tahap-tahap pengembangan dan setelah divalidasi oleh validator memenuhi kriteria yang ditentukan.

\section{Implementasi Perangkat Pembelajaran Berbasis SMART}

Implementasi perangkat pembelajaran berbasis SMART ini dilakukan pada siswa SMP Islam Pekalongan kelas VIII Pekalongan, tujuannya untuk mengetahui bahwa rata-rata nilai hasil belajar siswa yang pembelajarannya menggunakan perangkat pembelajaran berbasis SMART lebih baik dari pada yang kelas konvensional (kelas Kontrol). Untuk mengetahuinya dilakukan uji banding dengan maksud untuk membandingkan rata-rata prestasi belajar dari kelas uji coba perangkat dan kelas kontrol.

Hipotesis:

$\mathrm{H}_{0}: \mu_{1}=\mu_{2}$ ( tidak ada perbedaan nilai rata-rata prestasi belajar antara kelas uji coba perangkat dengan kelas kontrol)

$\mathrm{H}_{1}: \mu_{1} \neq \mu_{2}$ ( ada perbedaan nilai rata-rata prestasi belajar antara kelas uji coba perangkat dengan kelas kontrol)

Hasil analisis diperoleh terdapat perbedaan rata-rata nilai prestasi belajar siswa antara kelas uji coba perangkat dengan kelas kontrol. Besarnya perbedaan tersebut dapat dilihat pada Tabel 2 sebagai berikut.

Tabel 2. Rata-rata nilai TPB Kelas Uji Coba Perangkat dan Kelas kontrol

\begin{tabular}{|rl|r|r|r|r|}
\hline & Kelas & $\mathrm{N}$ & \multicolumn{1}{c|}{ Mean } & Std. Deviation & \multicolumn{2}{|c|}{ Std. Error Mean } \\
\hline TPB & UjiCoba & 30 & 70.33 & 6.671 & 1.218 \\
& Kontrol & 30 & 60.60 & 6.339 & 1.157 \\
\hline
\end{tabular}

Dari tabel di atas dapat dilihat bahwa rata-rata nilai prestasi belajar kelas uji coba perangkat yaitu 70,33 lebih besar dari rata-rata nilai prestasi belajar kelas control yaitu 60,60. Ini berarti rata-rata nilai prestasi belajar kelas uji coba perangkat lebih baik dari kelas kontrol.

\section{KESIMPULAN}

Penyusunan perangkat pembelajaran yang meliputi Silabus, RPP, Modul yang memenuhi kriteria SMART sebagai berikut: (1) pengukuran S pemilihan indikator materi sesuai dengan tingkat kemampuan siswa (2) pengukuran $\mathrm{M}$ bahwa indikator 
yang dipilih harus terukur, (3) pengukuran A bahwa ketercapaian atau prestasi dapat ditunjukkan ketuntasannya, (4) pengukuran $\mathrm{R}$ langkah program kerja dari awal hingga akhir (rencana pembelajaran) yang jelas dan dapat dilaksanakan secara konkret, (5) pengukuran T ketersediaan waktu dari penugasan, proses pembelajaran tatap muka, dan evaluasi harus jelas waktu yang disediakan. Implementasi perangkat pembelajaran berbasis SMART menunjukkan bahwa rata-rata nilai prestasi belajar kelas dengan menggunakan perangkat berbasis SMART lebih baik dari kelas kontrol. Ini juga menunjukkan bahwa dengan pembelajaran dengan perangkat pembelajaran seperti Silabus, RPP, dan Modul yang berbasis SMART yang digunakan guru, ternyata mampu membuat hasil belajar siswa yang lebih baik.

\section{DAFTAR PUSTAKA}

Boise State University. 2007. Performance management - Creating SMART Objectives: Participant Guide.

Depdiknas. 2008. Teknik Penyusunan Modul Tanggal 27 Februari 2008. Jakarta: Departemen Pendidikan Nasional.

Gafur, A. 1989. Disain Instruksional. Solo: Tiga Serangkai.

Iverson, A. 2003. Preparing Program Objectives Theory \& Practice. Toronto. Ontario: The International Development Research Centre.

Thiagarajan, S., Semmel, D.S. \& Semmel, M.I. 1974. Instructional Development for Training Teachers of Exceptional Children. Indiana: Indiana University Bloomington.

Trianto. 2007. Model Pembelajaran Terpadu dalam Teori dan Praktek. Jakarta : Prestasi Pustaka Publisher. 